\title{
IN TIMES OF WAR AND TERROR: PHILOSOPHICAL COUNSELLING AS AN ALTERNATIVE TO TREATMENT OF POST-TRAUMATIC STRESS DISORDER*
}

\author{
SHLOMIT C. SCHUSTER \\ Philosophical Counselor, Jerusalem, Israel
}

\begin{abstract}
In this paper I question some of the ideas behind mainstream psychological help provided and advocated by the American Counseling Association in situations that can be best described as life threatening. I contrast Post-traumatic Stress Disorder treatment with what I propose as the help philosophical counsellors can offer in crisis situations. I present an elementary description of the relatively new profession of Philosophical Practice, or Philosophical Counselling, and provide examples-taken from my philosophical practice in Israel, from philosophical theory, and from philosophers' autobiographies-that give legitimacy to the claims of philosophical practitioners.
\end{abstract}

\section{THE STATE OF POST-TRAUMATIC STRESS DISORDER AT THE BEGINNING OF THE $21^{\text {ST }}$ CENTURY}

Particularly in New York City, the crisis caused by the recent terrorist attacks against the United States created a great demand for counselling professionals claiming to know how to help traumatized persons. As of this writing, Dr. Bob Dingman, the New York Ground Zero Mental Health Officer for the American Red Cross, has been looking for many months for more and more certified counsellors: professional psychotherapists; family, school, and grief counsellors; clinical psychologists; and other mental health workers. Though all types of religious ministers and lay people also try to bring relief to those grieving or stressed, the demand for counsellors remains overwhelming.

There were also advisors such as the New York City Mayor Rudolph W. Giuliani who recommended that people continue life as normal, visit the regular pub or nightclub, the shopping mall, the opera house, museum, and so on. Other common sense and professional advice on how to cope with the "abnormal situation" was and still is given by the American Counseling Association (ACA), the world's largest professional counsellors organization. Before the terrorist attack, widespread American awareness of Post-traumatic Stress Disorder (PTSD) was limited largely to mental health professionals and Vietnam veterans; since September 2001, most Americans have heard about it.

* An earlier version of this paper had been translated to Italian and read as key lecture at the first conference of the Italian Society for Philosophical Counselling, 12 October 2002, Turin, Italy. Correspondence: Horkania 23, apt. 2, Jerusalem, 93305, Israel. Phone/Fax: 972-2-679-5090); email: counsel@actcom.co.il 
Insofar as the majority of the population in Israel-where I live and practice philosophical counselling-has not yet been informed about PTSD symptoms, we may count ourselves fortunate. Although Israel's population has been, for many years, extensively exposed to terrorism and wars, Israel's mental health workers seem not to be active in promoting PTSD consciousness among the public through far-reaching press campaigns such as have been prominent in the U.S. Sporadically some professionals organize a public lecture or conference on the subject. During the last four years the non-profit organization "Natal" (www.natal.org.il) has taken up the challenge of distributing information on PTSD, and this seems to be on a limited but increasing scale. In Israel there seems to be less tendency to grossly pathologize, in public, the distress ensuing from traumatic events with the label PTSD. Nevertheless, the distress is recognized and acted upon: the Israeli Social Welfare Ministry and other institutions usually dispatch an army of psychologists and social workers to support those directly or indirectly affected by terror and war-related disasters.

The American Counseling Association published on their web site a definition and a short list of the symptoms associated with the effects of terrorism: "10 Ways to Recognize Post-Traumatic Stress Disorder" (ACA, 2002). It claims that:

after a loss, it is normal to go through a natural grieving process. Sometimes, however, after a tragedy, such as a sudden traumatic event, feelings of loss surface several weeks or months after the tragedy occurred. This is called posttraumatic stress disorder (PTSD). Recognizing these symptoms in yourself or others is the first step toward recovery and finding appropriate treatment.

1. Re-experiencing the event through vivid memories or flash backs;

2. Feeling "emotionally numb;"

3. Feeling overwhelmed by what would normally be considered everyday situations and diminished interest in performing normal tasks or pursuing usual interests;

4. Crying uncontrollably;

5. Isolating oneself from family and friends and avoiding social situations;

6. Relying increasingly on alcohol or drugs to get through the day;

7. Feeling extremely moody, irritable, angry, suspicious or frightened;

8. Having difficulty falling or staying asleep, sleeping too much and experiencing nightmares;

9. Feeling guilty about surviving the event or being unable to solve the problem, change the event or prevent the disaster;

10. Feeling fears and sense of doom about the future.

ACA's general assumption appears to be that every American is traumatized by the events of the 11th of September. Irreversible alterations are said to have occurred in American life and with each individual American. At the ACA web site, Anne M. Brainerd (2001) stresses:

As a nation we have been traumatized, and as an individual you have been traumatized. Don't think that because you weren't on one of the planes or in one of the buildings, or didn't have family or friends in those places, that you weren't affected. Our lives as Americans, and each of us personally, have been irrevocably altered. 
I suggest we could consider these events as having international reverberations as well; Western and other advanced nations share in the aftermath of the collapse of the Twin Towers. It is perhaps not surprising that, during the first weeks following the Twin Tower disaster, some U.S. mental health practitioners turned to Israeli colleagues to learn from their experiences in dealing with terrorist attacks. More recently, some U.S. mental health professionals came to share the lessons they learned from working at Ground Zero with their colleagues in Israel.

PTSD is said to be "in many ways a normal response to an abnormal situation" (ACA, 2001). Likewise, ACA finds recognizing that one is in the grip of a "disorder" to be the first step to recovery and treatment. If one chooses not go into treatment immediately, one is advised not to deny these feelings (symptoms) and to keep oneself, family, and surroundings in control. The American Psychologist Association recommends that, when a person suffers the warnings signs of traumarelated stress for more than a month, he or she should get treatment. There are also other clinical opinions concerning PTSD, but the above guidelines seem authoritative at present; these are accepted by most professionals.

\section{ALTERNATIVES TO TREATMENT OF POST-TRAUMATIC STRESS DISORDER}

What seems problematic in PTSD diagnosis and treatment is that trauma becomes a metaphor for tragedy. In effect, tragedy becomes understood as identical to trauma. From this perspective, persons victimized, or others who have witnessed disaster, have to become affected by the tragic events, and trauma treatment is necessary. This conclusion denies the "lay knowledge" of persons affected by trauma; such persons may have the potential to self-treat "trauma." The suggestion that emotional wounds heal by themselves over time seems, from the PTSD perspective, to be but a tall tale.

The perspective implied by PTSD discourse suggests that people do not have the inner strength, character, or vitality to live with tragedy without becoming traumatized or disordered. Emotional distress as aftermath to a tragic event-although PTSD is acknowledged as a normal reaction-cannot be considered; it cannot be understood in itself as "in order" and as a part of normal life; it must be classified as a disorder. From a philosophical perspective one can question these notions of order and disorder, as Michel Foucault did in The Order of Things (1973) and Madness and Civilization (1988). From my viewpoint, many people with so-called "disorders" do not need psychological or other clinical treatment, but can manage and understand their lives and emotions from their own preferred perspective or order. For example, religious or philosophical approaches to emotional and cognitive management have proven themselves valuable alternatives. Although, at present, some philosophers characterize the discipline of philosophy as in crisis, a growing number of philosophers hold the classic view that philosophy is useful for daily life. It might even be useful in crisis situations.

Many psychological counselling approaches consider feelings to be the most important matter to be discussed and worked on. Though there is a growing awareness that existential and ethical questions trouble many counselling clients, trying to find answers to these questions is still considered to be a waste of counselling time. Questions born from tragic events are legitimate questions, yet these are matters 
easily done away with as a part of the million questions for which there are no answers. Consequently, most psychological counsellors do not seriously take up the great questions of life in their practice.

Abutting the apparent privileged place emotions have in psychotherapeutic treatment, modern Western society is apprehensive of persons expressing emotions, particularly strong emotions. Consequently people habitually suppress or deny feelings and do not learn to live resourcefully with feelings.

\section{A PHILOSOPHER'S FACTUAL HELP IN CRISIS}

As a philosopher, I have been operating a first-aid philosophy hotline since 1990. My approach is quite different from ordinary crisis counselling, yet many have found it helpful. I operate the first-aid philosophy hotline according to my conception of philosophical counselling, which is mainly based on the theorizing and praxis experience of Dr. G. B. Achenbach $(1985,1987)$. Since I already extensively described this approach elsewhere (Schuster 1991, 1998, 1999, 2002, 2003), here I will just outline some basic ideas of the approach.

In 1981, Achenbach opened a philosophical praxis in Bergisch-Gladbach, near Cologne. Achenbach began a dialogue with those searching for help from another perspective than that provided by psychiatrists, psychologists, other mental health workers, and spiritual guides. Some of Achenbach's visitors (visitors is the preferred term for clients in this profession) had already tried most of the usual remedies for anxieties, suffering, and existential questions. New in Achenbach's approach was that he offered an alternative to psychotherapy, but not an alternative therapy. Clinical diagnoses and treatment following the medical paradigm of therapy were absent in his approach, though philosophical counselling can have therapeutic results.

Four basic conceptions are characteristic of philosophical counselling: (a) sincere communication between the philosophical practitioner and the visitor based on a "beyond-method" method; (b) the importance of dialogue as that which enlivens-and as that which flows from being; (c) "Auslegen:" a looking for explanations, in which the practitioner becomes united with the problem, not by imparting her or his own understanding of it but by giving the visitor a fresh impulse to explain him or herself; and (d) the innovative component of dialogue, the element of wonder in philosophical practice, which does not allow for fixed viewpoints, standard attitudes, or permanent solutions.

I illustrate my claim that philosophical advice is a valuable alternative to what usually is offered as crisis counselling through sharing some of my own experiences during the Gulf War. The Gulf War was a very busy time for the philosophical first-aid line. In particular, many persons from the Tel Aviv area called me during those days. Most of them wanted to discuss their current confusion. Their questions were often ethically or existentially related: Should I stay in Tel Aviv in spite of the greater danger I risk there? Should I go to Jerusalem or another town where there are fewer chances to be hit by missiles? Would the last option make me less patriotic? Would I be betraying those remaining at home, in Tel Aviv? What is an ethical choice? What is the right thing to do? How can my life be meaningful in these circumstances? 
From an empathetic, open-minded, and critical philosophical viewpoint, there is no universal or absolute answer to these questions. Nevertheless, if the dialogue is problem- and person-centred, people may find direction and support through a philosophical exchange of ideas. Similarly, people in other kinds of personal distress may find comparable consolation and hope through philosophical counselling.

A war, or terrorist attacks, may intensify in persons the need to feel secure in ways that security services and psychologists cannot provide. Political leaders of nations may provide, through their rhetoric, an effective, but possibly superficial, first-aid in national crises by calling a war "an operation," or by giving it other impressive, lyrical, or even soul-soothing names. Philosophers schooled in rhetoric also can contribute to reducing anxiety, or to dealing with other war-related problems, by carefully applying words. However, to refrain from being superficial, or even deceitful, philosophical counsellors have to engage in an honest and profound face-to-face encounter, an I-thou dialogue, and develop an intimate conversation with those oppressed by anxiety and depression. The book of Ecclesiastes already praises wisdom to be better than strength, and better than weapons of war. Today, the writer of that ancient book would have added: "and better than tranquilizers."

\section{PHILOSOPHICAL REFLECTION ON CRISIS INTERVENTION}

So far, few people have considered philosophical reflection as an adequate remedy in crises, or as compatible with psychological counselling or psychiatric treatment. However, Karl Jaspers (1951), a psychiatrist and philosopher, described philosophizing in what he called "border situations" as very appropriate, and psychiatrist R.D. Laing (1970) introduced philosophy as a core method in crisis intervention.

Psychiatrist Peter R. Breggin and social work professor David Cohen (2000) promote a philosophical lifestyle as the cornerstone for well-being (i.e., a commitment to a loving, zestful, rational, and principled life). These authors show that people suffering from intense or painful emotions do not need to be understood as "mentally ill." They argue that naming strong emotions (e.g., a "panic disorder" or a "clinical depression") adds a medical aura to these feelings. Instead of suppressing these powerful emotions by drugs, they suggest letting them be: "Even when you feel overcome or swept away by an emotion, you need not do something right away to stop the emotion. You can learn to have feelings without being driven to do anything about them." Breggin and Cohen believe that drugging powerful feelings away causes a harmful psychological and spiritual blindness.

As long as 50 years ago, the philosopher-theologian Paul Tillich provided many philosophical answers for people in the grip of fear and anxiety. In The Courage to Be, Tillich $(1952$, p. 77$)$ claimed: "Existential anxiety has an ontological character and cannot be removed but must be taken into the courage to be. Pathological anxiety is the consequence of the failure of the self to take the anxiety upon itself. Pathological anxiety leads to self-affirmation on a limited, fixed, and unrealistic basis and to a compulsory defense of this basis (fanaticism)." Tillich showed how the ancient philosophers taught courage as a way of life, hence providing a philosophical paradigm by which persons could come to terms with existential anxiety. 
This type of courage was related to wisdom and ethics; indeed, it was the domain of the guardians and the rulers in Plato's utopian state. It is not merely bravery or fortitude. For example, in the Nicomachean Ethics, Aristotle (1941, III:7) found that the courageous person acts for the sake of what is noble: "Now the end of every activity is conformity to the corresponding state of character. . . . Therefore it is for a noble end that the brave man endures and acts as courage directs" (p. 976). In the Stoics, particularly Seneca, courage to be is located in the control of persons by reason. And, according to Stoic doctrine, anxiety or fear is nothing but the fear of fear itself. Seneca and Epictetus thought similarly about this issue. One may learn to be fearless by affirming oneself as not bound by natural desires; Stoic happiness and strength of soul are found by transcending all circumstances.

Tillich views Spinoza and Nietzsche as the modern representatives of the courage to be; their views on how to overcome anxiety are similar to those of the ancient philosophers. The 20th century existential movement is understood by Tillich (1952) as an attempt to confirm in oneself meaninglessness and despair. Kierkegaard, Heidegger, and Sartre also present the modern way to affirm existence in the face of anxiety and despair. Finally, Tillich describes modern theology as a way to overcome the anxiety of meaninglessness.

Tillich's final chapter of The Courage To Be (1952), "Courage and Transcendence," can be compared with Martin Buber's reflections on the book of Job. Tillich regards mystical experience and the divine-human encounter as one among many sources of courage. Buber (1968) shows how the supra-human suffering of Job is related to the need for divine-human encounter. Job suffers because God is hiding his face; there is a lack of seeing and hearing the Creator. Buber finds that "the overcoming of the riddle of suffering can only come from the domain of revelation, but it is not the revelation in general that is here decisive, but the particular revelation to the individual: the revelation as an answer to the individual sufferer concerning the question of his sufferings, the self-limitation of God to a person, answering a person" (p. 196).

\section{PHILOSOPHICAL NARRATIVE AS AN ALTERNATIVE STRATEGY TO DEAL WITH TRAGIC SITUATIONS}

Philosophical counsellors and their clients can also learn how to live with, or transcend, the issues related to violence, terrorism, and war. Historical records show that philosophers and eras of war existed together over the ages. There are many accounts describing how philosophers lived in times of crisis, and how those times influenced their philosophy.

However, in order to be edified by war narratives, one need not remain in the domain of philosophy. The Encyclopedia of Life Writing (Jolly, 2001) has a considerable number of pages covering several genres in war writing (e.g., diaries, journals, letters, novels, and autobiographies). The great Western literary classics, Homer's Iliad and Odyssey, are said to have established the tradition of describing the events of war.

The Meditations-or, as Marcus Aurelius Antoninus (Aurelius, 1965) named it, To Himself_-an early philosophical "war time" text was written by Aurelius not 
to portray himself so much as to propose "[in] the midst of the noise of war, . . . by means of these notes to keep permanently before his mind the outlook on life which he had gained from his philosophical studies, in order to direct his daily life by that outlook" (Misch, 1950, p. 444). Augustine's City of God (1950) was inspired by the cataclysmic historical event of his days: Rome being conquered by the Arian Goths. Dante's life was affected through warring emperors and popes. The Divine Comedy cannot be detached from Dante's (1989) wanderings and afflictions caused by these tragic circumstances. Erasmus, although a counsellor to Emperor Charles $\mathrm{V}$, suffered much from warring political and religious parties.

Russell, Wittgenstein, and Sartre are some modern examples of philosophers whose philosophizing was influenced by war events. Ivory towers and their inhabitants are not less vulnerable to war machinery than any other towers.

Bertrand Russell (1989) considers how his life was divided in two by the First World War. The period from 1910 to 1914 was a time of inner transition for him, but changes in his understanding of human nature came as an effect of the war. $\mathrm{He}$ writes in his autobiography:

I was living at the highest possible emotional tension. Although I did not foresee anything like the full disaster of the War, I foresaw a great deal more than other people did. The prospect filled me with horror, but what filled me with even more horror was the fact that the anticipation of carnage was delightful to something like ninety percent of the population. I had to revise my views on human nature. At that time I was wholly ignorant of psycho-analysis, but I arrived for myself at a view of human passions not unlike that of the psychoanalysts. I arrived at this view in an endeavor to understand popular feeling about the War (p. 240).

Russell considered the war to be a grave mistake, and became an anti-war activist. An article in which he defended pacifism led to a six month imprisonment, during which time he worked on his Introduction to Mathematical Philosophy.

Simone de Beauvoir and Jean-Paul Sartre ascribe essential changes to their understanding of life and ways of living to the Second World War. Sartre began keeping a journal during the war. Annie Cohen-Solal (1991), an eminent biographer of Sartre, observes that, "Next to the Diaries and daily introspection, philosophical practice also plays an important role in this period of Sartre's life. It protects him [quoting from Sartre's The War Diaries] 'against the melancholy, moroseness, and sadness of life" (p. 142). During the war, Simone de Beauvoir seemed to find comfort by continuing her journal, worrying about Sartre, communicating with him, and by reading The Journals of André Gide. In these journals, Gide (1959) exposed in more than a hundred pages his personal life during the years of the First World War.

Sartre's trilogy, The Roads to Freedom $(1963,1968,1973)$, that so well describes the Second World War and its effects on people, was partly written during the war. Cohen-Solal (1991) reports Sartre's comments in a letter about this book:

there are moments when I feel funny knowing that, as I write, there are people dying like flies up North, and that the destiny of Europe is at stake. But what can I do about that? This is my destiny, and no collective terror can make me renounce it. . . . My novel must be finished by June 15. That's all there is to it. Then, it will no longer depend on me. . . . Still, I can only see my writing as a 
symbolic gesture against the fall of democracy and freedom and against the defeat of the Allies (p. 145).

Paradoxically, Sartre's experience as a prisoner of war greatly contributed to his understanding of freedom as developed in his post-war existentialism.

We can now realize that most of the great philosophers living during the first half of the 20th century have been, to a greater or lesser extent, exposed to wars and that their philosophies were, to a greater or lesser extent, the meaningful products of these times. These philosophers do not seem to have been helpless victims of their emotions, suffering from sleepless nights and nightmares, in the grip of a syndrome, or in need of therapy, counselling, or psychiatric drugs.

On the basis of the above records, I argue that, in spite of war experiences or even due to periods of terrorism, philosophers created meaningful philosophies of life. Yes, philosophers asked the great questions of life and they also tried to answer them, and many found answers that were helpful for them. Others surrounded by terror and war may find meaning and comfort by knowing how philosophers lived during tragic times, and dwell on the questions and answers these philosophers produced. Philosophical inquiries can be helpful for people in their specific tragic situations. One does not have to accept all or any of these answers, but it is obvious that philosophical activity can provide answers. Further, that there are answers for some people, and that the quest for answers itself might have value, does not mean that something is wrong with persons who cannot bear looking for answers or finding them.

\section{THE WILL TO COMFORT VERSUS THE WILL TO TRAUMA}

During the many months of what has become known as the Second Palestinian Uprising (or Intifada), I encountered often among those grieving or those who have been the immediate victims of terror attacks something that I name "the will to trauma." The depth or vastness of tragic events become illustrated, defined, or honoured by proclaiming the emotional pain experienced as something from which it is impossible to be healed. Proclaiming the pain everlasting, the wounds forever bleeding, is the romantic evidence of an immense love felt for the person, or persons, or the quality of life that has been lost. Here one encounters a commitment to tragic emotion, that may prove itself "justified" in its desire for pain. One must respect the will to trauma and traumatization.

However, it seems to me that there are other, and possibly better, ways to live with tragic events. The will to comfort, including also the will to receive comfort, seems to me to be a better attitude. To comfort and to be comforted can even be considered as an ethical, religious, or emotional duty. In addition, Aaron Antonovsky's (1988) salutogenic model in medical sociology shows that persons' orientation towards health and wellbeing make an essential difference from an orientation focusing on, and consequently leading to, a pathological course. However, perhaps paradoxically, some people only find comfort and wellbeing by proclaiming themselves or others inconsolable (such romantic tendencies could be understood as narcissistic from a psychoanalytic viewpoint). 


\section{UNDERSTANDING THE CONTEXT OF TRAGIC EVENTS PHILOSOPHICALLY}

A different use of philosophical practice and counselling, but not less helpful, can be the philosophical analysis of a distressing political or social situationparticularly so if these situations seem confusing or incomprehensible. Also, understanding situations from a philosophical perspective may help people cope with the anxiety caused by them. It seems that any understanding of causes and circumstances creates in people a sense of having some control over the situation.

Most psychoanalytic understandings of violence and terror, however, may point persons only to the need for being psychoanalyzed. On the basis of the psychoanalytic, social, and political scientific understandings of Melanie Klein, Harold Laswell, and Karen Armstrong, the psychoanalyst Robert Young (2002) illuminates the origins of terrorism and fundamentalism through the Freudian notion of regression: terrorists and fundamentalists simplify their reality because they feel deeply threatened. Their problem is not caused by outer circumstances but by not having received in early infancy what they needed. Accordingly, they "suffer from phantasies of annihilation and defend themselves against these psychotic anxieties with rigid views." In contrast to these deterministic personality understandings one may envision people and situations through other paradigms. For example, Michael McCubbin (2001) has presented a competing paradigm: the "Art of the Possible," a teleological human science.

In "Suicide bombers, authoritarian minds, and the denial of others," Adrian Mirvish (2001) presented an exemplary philosophical analysis of the present situation in the Middle East. Mirvish brings a Sartrean perspective to the international and Israeli war on terrorism. But, more than that, he sheds light on how people in general can live together in peace.

First of all, he rejects the general deceptive stereotyping of "good guy versus bad guy" Muslim, usually applied to understanding the terrorist organizations. In Sartrean terms he describes terrorists as individuals that want to capture and manipulate the freedom of others. But suicide bombers go further: "By contrast, for Al Qaeda, Hamas, and company, the desire is for control in the form of destruction and not manipulation. The aim, unabashed, lies not in any sense of affirmation, but rather in the obliteration of the other." Mirvish (2001), again in Sartrean terms, considers such extreme destruction to be a form of denial:

the Sartrean-type denial, paradoxically, starts with the affirmation of the existence of the other, whereas in the terrorist case, denial goes so far as to refuse or reject the other's existence from the very start. In both cases there is the drive for the imposition of homogeneity, but with the former the one controlling not only struggles but enjoys imposing his stamp on what was different or other than himself. For the terrorist, the desire for homogeneity is so strong as to provoke an incessant move to blot out even the possibility of any difference.

The extreme desire for homogeneity makes the terrorist inhuman in that others are merely "non-others, pseudo human forms to be disposed of, or tolerated with indifference at best." Adorno's (1993) understanding of the authoritarian personality presents as well the goal of extremists as aiming to achieve absolute homogeneity within and around themselves. 
Mirvish's solution for this season of terrorism is a long-term one. He observes that the drive for homogeneity is encouraged by fundamentalist and totalitarian governments. Pluralistic and democratic politics would breed different attitudes, and encourage the authentic affirmation of others as others. Referring to one of Sartre's later works, the posthumously published Notebooks for an Ethics, Mirvish looks beyond political and social reform, and shows the need for individuals to become a "fraternity" through ethical attitudes such as tolerance and solidarity with the other as other. Or, in other words, the dangerous drive towards absolute homogeneity can be countered by authentic friendships between individuals.

Mirvish concludes his analysis with accentuating the need for societies, particularly Muslim societies, to accept alterity in their own ranks, claiming that the social order for peace has to start at home. I find this Sartrean explanation of the dynamics of terrorism helpful in that it shows the problem not bound to a particular religion, nation, economics, or sociological-pschoanalytical development. Terrorism, and possibly other uses of violence as well, is bound to the lack of certain ethical attitudes, such as tolerance and solidarity between human beings. Appreciating and promoting tolerance and solidarity as everyday values at home and abroad may indeed be a first step towards ending wars on terrorism, and towards being at peace with oneself.

Mirvish's interpretation shows Sartre's mild side, and the revolutionary Sartre from the Critique of Dialectical Reason (1982) seems to be lost, or out of sight. In the Critique, Sartre describes hope and terror, freedom and violence as indissolubly united in revolutionary activity. Yet, terror and violence are symptoms of an alienated society, and terror is a first step in a process to freedom and de-alienation. However, alienation could have been treated in a different manner, and terror might have been prevented.

I am impressed by the resemblance of Mirvish's philosophical analysis of a political situation with a kind of communication that occurs in the realm of psychotherapy when-from my point of view-therapy goes wrong. That is when the relationship between a patient and therapist becomes hostile, violent, or breaks down completely. Instead of condemning such violence as the problem of the person who is violent, as the evidence of the patient's disorder, I propose to understand so-called patient hostility through the principle of tolerance and solidarity between human beings. This would show a patient's violence in a totally different light. For example, violence is the expression of the patient's desire for de-alienating the unauthentic relationship in which he or she is caught. It could be seen, then, as a first step towards greater understanding in actual inter-human and authentic relationships. When reacted upon in the right manner by the therapist, it could become a step towards true freedom and friendship. These matters seem to me all of vital importance in philosophical counselling; philosophical counselling should promote an authentic dialogue between equal, not alienated or second-class, human beings. It should be a dialogue that looks for creating ethical friendships between people.

Accordingly, in times of war and terror, philosophical counselling seems to go beyond PTSD treatment in helping people deal with their personal anxieties, but also in creating alternative conceptual frameworks to understand the issues that produce terror and war. Next, it can provide tools as a remedy to violence by illuminating 
the source of terror and by empowering others to start a dialogue that seeks an end to alienation and war. Though this is a pretentious claim, I do believe it valid and worth promoting. A philosophical counsellor who philosophizes with his or her client on war and terrorism related anxiety, fear, suffering, guilt, or other problems, might help the client-and also society at large-to live resourcefully and well with these issues.

\section{RÉSUMÉ}

Dans ce texte, je questionne certaines idées sous-jacentes à l'aide psychologique couramment dispensé et valorisé par l'American Counseling Association, pour les situations impliquant une menace pour la survie de la personne. Je contraste le traîtement du désordre de stresse post-traumatique avec ce que je propose, à savoir l'aide qu'un conseiller ou une conseillère philosophique peut offrir dans des situations de crise. Je présente une description élémentaire de la profession relativement nouvelle de praticien ou praticienne philosophique, qu'on nomme aussi counseling philosophique; je fournis également quelques exemples qui donnent une légitimité aux revendications des praticiens et praticiennes philosophiques. Ces exemples proviennent de ma pratique philosophique en Israël, de la théorie philosophique et d'autobiographies de philosophes.

\section{REFERENCES}

Achenbach, G.B. (1987). Philosopische Praxis. Köln: Jūrgen Dinter.

Achenbach, G.B., \& Macho, T. (1985) Das prinzip heilung. Köln: Jūrgen Dinter.

Adorno, T.W. (1993). The authoritarian personality. New York: Norton.

American Counseling Association. (2002). Crisis fact sheet. Retrieved from http://www. counseling.org/consumers/ptsd.htm, last accessed January 29, 2003.

Antonovsky, A. (1988). Unraveling the mystery of health: How people manage sress and stay well. London: Jossey-Bass.

Aristotle. (1941). Nicomachean ethics. In R. McKeon (Ed.), The basic works of Aristotle (pp. 935-1112). NewYork: Random.

Augustine. (1950). The city of God, Vol. 1 (Ed. R.V.G. Tasker). London: Dent.

Aurelius, M. (1965). To himself. In M. Hadas (Ed.), The essential works of stoicism (pp. 103-205). New York: Bantam.

Brainerd, A. M. (2001). Tragic events and the effects on all of us. Retrieved from $A C A$, The counseling corner http://www.counseling.org/consumer/corner1001.htm\#2, last accessed January 29, 2003.

Breggin, P.R., \& Cohen, D. (2000). Your drug may be your problem: How and why to stop taking psychiatric medications. Cambridge: Perseus.

Buber, M. (1968). Job. In N. N. Glatzer (Ed.), On the Bible (pp.188-210). New York: Schocken.

Cohen-Solal, A. (1991). Sartre: A life. London: Minerva.

Dante, A. (1989). The divine comedy. New York: Oxford University Press.

Foucault, M. (1973). The order of things. New York: Vintage.

Foucault, M, (1988). Madness and civilization. New York: Vintage.

Gide, A. (1959). The journals of André Gide. New York: Vintage.

Jaspers, K. (1951). The way to wisdom. New Haven, CT: Yale University Press.

Jolly, M. (Ed.) (2001). Encyclopedia of life writing. London: Fitzroy Dearborn.

Laing, R.D. (1970). The divided self. Harmondsworth: Penguin.

McCubbin, M. (2001). Free will, rationality, and explanation in the human sciences. Review of Existential Psychology \& Psychiatry, 26, 39-55. 


\section{CANADIAN JOURNAL OF COMMUNITY MENTAL HEALTH}

Mirvish, A. (2001). Suicide bombers, authoritarian minds, and the denial of others. Judaism, a Quarterly Journal of Jewish Life and Thought, 200 (50). Retrieved from http:// humwww.ucsc.edu/judaism/current, last accessed January 29, 2003.

Misch, G. (1950). A history of autobiography in antiquity, Vol.1. London: Routledge.

Russell, B. (1989). Autobiography. London: Unwin

Sartre, J.P. (1963). The reprieve. Harmondsworth: Penguin.

Sartre, J.P. (1968). Iron in the soul. Harmondsworth: Penguin.

Sartre, J.P. (1973). The age of reason. Harmondsworth: Penguin.

Sartre, J.P. (1982). Critique of dialectical reason. London: Verso.

Schuster, S.C. (1991). Philosophical counseling. Journal of Applied Philosophy, 8, 219-223.

Schuster, S.C. (1998). On philosophical self-diagnosis and self-help: A clarification of the non-clinical practice of philosophical counseling. International Journal of Applied Philosophy, 12, 37-50.

Schuster, S.C. (1999). Philosophy practice: An alternative to counseling and psychotherapy. Westport, CT: Praeger.

Schuster, S.C. (2002). Hoop en troost in tijden van oorlog: De filosofisch consulent als crisis hulpverlener? (Hope and comfort in war time: The philosophical counselor as crisis relief worker?)." Filosofie, 12, 40-41.

Schuster, S.C. (2003). The philosopher's autobiography: A qualitative study. Westport, CT: Praeger.

Tillich, P. (1952). The courage to be. New Haven: Yale University Press.

Young, R.M. (2002). Psychoanalysis, terrorism and fundamentalism. In The writings of Professor Robert M. Young. Retrieved from http://human-nature.com/rmyoung/papers/ pap135.htm, last accessed 29 January 2003. 